\title{
Cloning technique 'reveals legal loophole'
}

[LONDON] Concerns over a possible loophole in UK law that could allow the cloning of humans have been stimulated by the publication this week of research results describing the work of scientists in Scotland who have successfully cloned a lamb from cells of an adult sheep (see page 810).

Some claim the technique, which could in theory be used to clone humans, may not be covered by the Human Fertilization and Embryology Act of 1990, which is intended to outlaw human cloning, as it uses cells taken from adult organisms.

"My view is that the legislation is restricted to [prohibiting] the cloning of embryos," says Sheila McLean, professor of law and ethics in medicine at the University of Glasgow. "But this technique is not about embryos, it is about adults."

The 1990 act states that an embryo cannot be created outside the human body without authorization. It says permission will not be given to "replacing a nucleus of a cell of an embryo with a nucleus taken from a cell of any person, embryo, or subsequent development of an embryo".

David Shapiro, executive secretary of the London-based Nuffield Council for Bioethics, argues that any possible weaknesses in the law should be eliminated as soon as possible. "If there are legal doubts, the matter should be resolved quickly and legislation brought in."

This view is echoed by Baroness Mary Warnock, who chaired the government advisory committee on human fertilization and embryology whose report, published in 1984 , formed the basis of the 1990 act.

Warnock says that the act could only include research that was current at that time. "We didn't know about the possibility of cloning from adult cells, and the act probably now needs to be amended to outlaw all human cloning."

The research has been carried out by scientists from the Roslin Institute in Edinburgh, part of the Biotechnology and Biological Sciences Research Council, and PPL Therapeutics, an Edinburgh-based biotechnology company which conducts research into breeding animals for medicinal products such as human protein.

The findings were prematurely disclosed by a British newspaper last weekend. Following publication of the news, the value of PPL's shares rose 25 pence to around $\mathfrak{£} 3.60$ (US\$5.80) on Monday morning.

The research builds on a paper published last year (see Nature 380, 64-66; 1996) reporting on work by the same researchers in which they successfully cloned lambs from the cells of embryos. This time, however, they used the nucleus of cells from an adult sheep and placed it in an unfertilized egg which had its nucleus removed. This was then artificially

inseminated into a surrogate sheep. A lamb, named Dolly, which is genetically identical to the donor sheep, was born a few weeks ago.

A spokesman for PPL dismissed fears on Monday that the technology could lead to the cloning of humans, partly because scientists agree that such a step would be unethical. But ethical and religious organizations have voiced concern at the potential implications.

Nicholas Coote, assistant general secretary of the Roman Catholic Bishops Conference of England and Wales, says that every human being has the right to two biological parents. At the same time he disagrees with those who suggest that the ability to selfreproduce contradicts the Church's teachings that individual creation is unique. "If I have a clone of me, I am still unique as my clone has a consciousness that is not mine."

Jeremy Rifkin, president of the Foundation on Economic Trends in Washington DC, is heading a worldwide coalition of 300 religious and ethics organizations which responded to the news of the Edinburgh work by demanding a worldwide ban on human cloning, suggesting that it should carry a penalty "on a par with rape, child abuse and murder".

Representatives of other church organizations have also voiced concerns. However, they differ over the extent to which cloning should be used, even in animals. Martin

\section{Japan decides to burn plutonium stocks}

[ TOKYO] Faced with a series of setbacks to its fast-breeder reactor programme, Japan has decided to push ahead with proposals to burn its growing stockpile of plutonium in conventional light-water nuclear reactors.

Last week, the Federation of Electric Power Companies approved a plan to use mixed plutonium-uranium fuel (MOX) in conventional reactors. Under the plan, MOX will be used in four reactors belonging to Tokyo Electric Power Company and Kansai Electric Power Company from 1999.

By 2010, the practice will have spread to between 16 and 18 reactors operated by 11 utility companies. The federation's move follows a decision earlier this month by the government to accept a recommendation from the Atomic Energy Commission to push forward with what is called the "pluthermal" programme.

The hands of both the government and industry have been forced by serious setbacks in the development of fast-breeder reactors. Technical difficulties meant that the government had repeatedly to delay the forecast start of commercial fast-breeder reactors from a date of 2010 set in the early 1980 s to the present estimate of around 2030.
Robra, executive secretary of the World Council of Churches, says there should be a moratorium on research and application of cloning techniques until ethical questions are satisfactorily resolved.

But Mary Seller, a member of the Church of England's Board of Social Responsibility, says that "the antics of a few cranks and Hitler types" should not interfere with such research. "Cloning, like all science, must be used responsibly. Cloning humans is not desirable. But cloning sheep has its uses," says Seller, who is reader in developmental genetics at the United Medical and Dental School of Guy's and St Thomas's Hospitals in London.

EhsanMasood

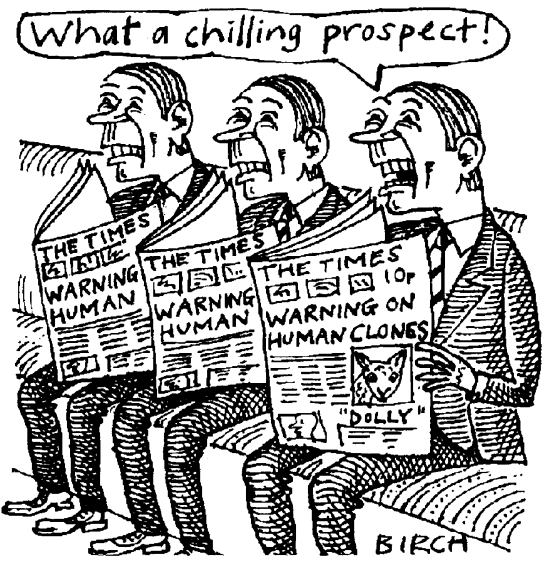

But even that now seems optimistic following a sodium leak at the Monju fastbreeder reactor that has stopped the fastbreeder programme in its tracks. Some industry observers believe that Japan will never have commercial breeder reactors because industry now sees them as commercially nonviable.

This leaves the serious problem of dealing with Japan's growing stockpile of plutonium derived from the reprocessing of spent nuclear fuel, which could in theory be diverted to produce nuclear weapons.

The government and electricity industry still face a major hurdle in meeting the proposed schedule for introduction of MOX fuel. The governors of Fukui, Niigata and Fukushima prefectures, where two-thirds of Japan's nuclear reactors are located, have both told the central government in Tokyothat they will not license reactors to burn MOX until the Monju accident is thoroughly investigated.

The government released a report on Monju last week confirming that the sodium leak was caused by the fracture of a thermal probe in the sodium cooling system (see Nature 379, 196; 1996).

David Swinbanks 